\title{
河口域の人為改変に伴うリュウキュウアュ 仔稚魚の生理的生息条件に対する影響評価 EVALUATION OF ESTUARINE HUMAN IMPACT ON FISH LARVA HABITAT IN POINT OF PHYSIOLOGICAL CONDITION
}

\author{
大槻順朗 1 島谷幸宏 2 \\ Kazuaki OHTSUKI and Yukihiro SHIMATANI \\ 1正会員 博（工） 東京理科大学助教 理工学部土木工学科（广278-8510 千葉県野田市山崎2641） \\ 2フェロー 博 (工) 九州大学大学院教授 工学研究院環境都市部門（†819-0395 福岡市西区元岡744）
}

\begin{abstract}
Our target species, Ryukyu-Ayu (Plecoglossus altivelis ryukyuensis) are thought that they are facing on distinct because of high water temperature in estuary of their habitat on their juvenile stage. It is necessary for conservation to evaluate how that condition effect on Ryukyu-Ayu. The aim of this study is to investigate an impact on their habitat suitability caused by development in estuary. To evaluate this we tried to apply the result of survival experiment on Ryukyu-Ayu larva to actual sites. This means we built statistical model to estimate 24 hours survival rate (ESR) from the experiment results and calculate ESR using field observation data of water temperature and salinity. The results show The ESR in habitat of artificial estuary is less than $40 \%$ even though more than $80 \%$ in all observation point in natural estuary and that carry out $1{ }^{\circ} \mathrm{C}$ water temperature falling can provide about $20 \%$ ESR rising.
\end{abstract}

Key Words : HABITAT EVALUATION, WATER TEMPARATURE, SALINITY, ESTUARY, TIDAL FLAT, AMAMI ISLAND, RYUKYU-AYU (Plecoglossus altivelis ryukyuensis)

\section{1. はじめに}

河川河口域は基礎生産力の高さによる餌資源の豊富さ と汽水の生理的柔和性から両側回遊魚を中心とした多く の魚類仔稚魚の生息域として重要である ${ }^{1)}$ 。近年河口域 の人為改変による環境の変質が生態系に多大な影響を与 えていると認識され，改変による物理環境の変化等で研 究が進む一方, 物理環境の変化が生物生態系に与える影 響については依然として研究事例が少ない現状にある.

本研究の対象生物種であるリュウキュウアユ

(Plecoglossus altivelis ryukyuensis) は奄美大島の夕に生 息寸る絶滅危惧種（環境省RD，CR登録）である．本種 は本土に生息するアユと概ね類似した生活史を持ち2)，

11-12月から3月頃までに河川下流の瀬で産卵を行い，1 月を盛期とし12月から4月まで河川汽水域を中心に出現 する ${ }^{3)}$ 。河口から沿岸域に多く出現するカイアシ類を主 に捕食しながらおよそ70日間滞在し成長すると遡河を開 始する. 河口域に広大な干潟・マングローブ域を持つ役 勝川では多くの個体数が確認される一方, 河口干潟の埋 め立てによる人為改変を被っている河内川においては個 体数が少ない状態が続いている2)。この要因について,
河内川河口域では仔稚魚の生息域における水温が $20^{\circ} \mathrm{CW}$ 上と高すぎることが指摘されている3) 4) 5)。冬季(3月)の 奄美大島河口域では約 $16^{\circ} \mathrm{C}$ で低温の河川水と約 $21^{\circ} \mathrm{C}$ で高 温の海水が相互影響することで概ね水温環境が形成され ている 。干潟域には，夜間の干出時に冷却され冷源と して機能するなどの水温低下機能があり ${ }^{6)} ，$ マングロー ブにおいても遡上海水の泠却効果が確認されており7), 河口域の変質による流動場等物理的特性の変化がリュウ キュウアユ仔稚魚の生息環境を悪化させた可能性がある.

このようにリュウキュウアユ保全に向けて河口の水温 管理は重要と考えられ, 現況の河口域の生息場評価や過 去・未来の水温環境の変化による生息場への影響の評価 が重要であると考えられる。一方, 仔稚魚の生存試験結 果によれば8) 生存率は同じ水温でも塩分濃度に左右され るので，水温の影響を検討するには塩分濃度も加えた評 価の仕方をする必要がある.そこで生存試験結果を現地 に適用し実験場の推定值を求め比較・感度分析を行なう ことは有用と考え, それにより現在の個体数減少要因が 生理的好適環境の相違で生じているのか否か，また，現 在の生息分布が生理的好適度の良否によって決定されて いるか否かを判断できると考えた，本論文では役勝川お 


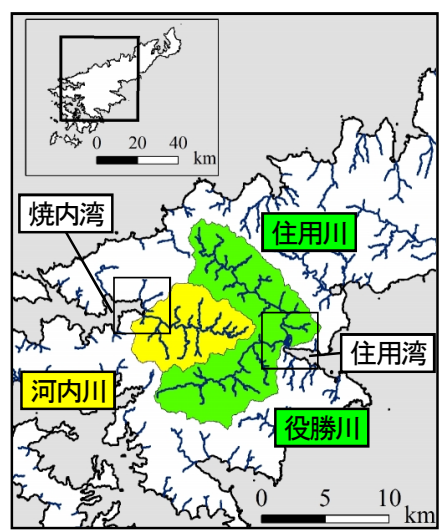

a）奄美大島

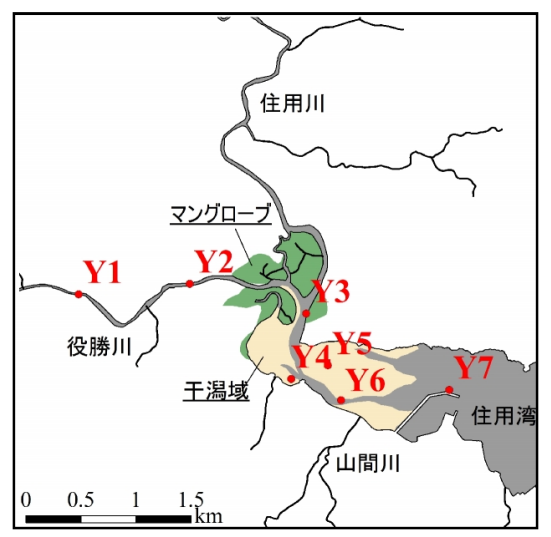

b）役勝川河口域

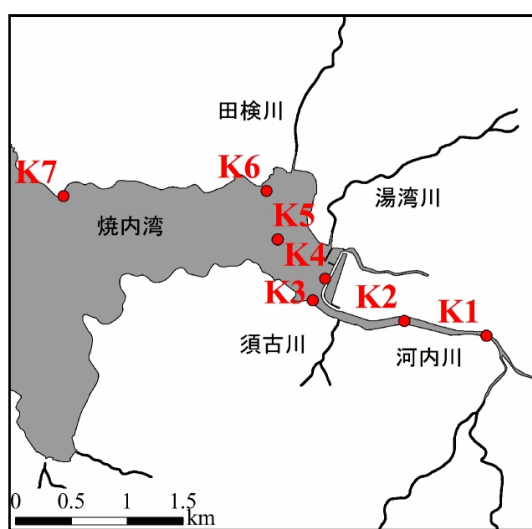

c）河内川河口域

図-1 調查地点位置図

よび河内川両河口域のリュウキュウアユ仔稚魚生育域環 境の差異がもたらす影響の評価を目的とし，仔稚魚生存 試験結果の統計的モデリング，水温・塩分濃度観測，及 びこれらの重ね合わせによる現場における生存率の推 定・比較を行った結果を述べる.

\section{2. 手法}

\section{(1) 対象地概要}

研究対象地は鹿児島県奄美大島東部・住用湾に注ぐ役 勝川河口及び同島西部・焼内湾に注ぐ河内川河口である

（図-1）。役勝川は流域面積 $46.4 \mathrm{~km}^{2}$ の2級河川で，河口 において同じく2級河川の住用川（流域面積 $46.4 \mathrm{~km}^{2}$ ） と 合流する，河口部は国定公園に指定され，約71haのマン グローブ域とその下流部に約100ha干潟域がある。 マン グローブはメヒルギが優占種であり,干潟域の底質はや やシルトを含む砂質である.リュウキュウアユ仔稚魚の 生息域はY2からY6にかけての河口域の澪筋の表層を中 心に比較的広範囲で観察される ${ }^{4)}$ 。河内川は流域面積 $39.7 \mathrm{~km}^{2}$ の2級河川で，役勝川，住用川とは流域を隣接し ている. 河口域は1954年の工事開始より干潟域の埋め立 てによる大規模な人為改変を被っており，水質上の問題 は露見していないものの河道の直線化・狭险化が起こっ ている.リュウキュウアユ仔稚魚生息域は埋め立て区間 末端の実質的な河口付近であるK3及びK4に局所的に分 布している゙).

\section{（2）現地観測とデータの取捨}

図-1 b）c）に示寸役勝川7地点，河内川7地点，計14 地点において水面下 $10 \mathrm{~cm}$ 表層水温及び塩分濃度を 1 分 間隔で観測した。観測日時は2010年3月3日-4日（役勝川 河口域），同3月5日-6日（河内川河口域）である。それ ぞれ大潮，中潮に当たる。観測機器は水温塩分計 (COMPACT-CT:アレック電子社製) を用いた．各計測 時において別途水準測量から得た地盤高と気象庁奄美験 潮所観測潮位を比較し，地盤高と潮位の差が $15 \mathrm{~cm}$ 以下
の場合干出していると見なし，当該地点・時刻における 観測結果を削除した．澪筋や海域など常に干出しないこ とが確認されている地点はデータの取捨は行わなかった。

\section{（3）生存率推定モデルの構築と生存率推定方法}

リュウキュウアユ仔稚魚の生理的な好適度を定量化す るために，室内絶食生存試験結果のモデル化を行った. 元データとなるリュウキュウアユ生存試験 $\left.{ }^{8}\right)$ は, 採取直 後の餒化仔魚, 日齢15-20日仔魚, 日齢50日仔魚の3成長 段階の仔魚に対して，恒温・恒塩分濃度・絶食条件下で すべての試験個体の死亡が確認されるまで行われた．モ デル化においては，水温・塩分濃度とも最も多い3環境 下（水温: $15 ， 19 ， 21^{\circ} \mathrm{C}$ ，塩分濃度:0，15，30psu）で実 施され，試験個体数が最も多く（各試験区につき3回， 平均 11.7 個体）十分にモデル化が可能な餒化仔魚期に対 する試験結果を用いた．試験結果から成長段階を経るに 従い塩分而性が高くなるが，本研究においては最も而性 が低く保全上重要な餒化仔魚期のみを対象とし，他の成 長段階についても類似の脆弱性を示寸と仮定して評価を 行った. 生存試験結果のモデル化には目的変数に仔稚魚 の生存率，説明変数に水温 $(T)$, 塩分濃度 $(C)$, 継 続時間 $(t)$ をとる一般化線形モデルを用いた。 リンク 関数はロジット関数を用い，誤差構造には2項分布を用 いた．線形予測子の式形は各パラメータと実測生存率の 関係を参考に，水温，塩分濃度については最適值の存在 が予測されることから2次項型で，経過時間礼ついては 経過時間の増加に従って生存率の低下量が急激に低下寸 ることから対数型とした. 寸なわち検討した式形は以下 の式（1）の通りである.

$$
\begin{aligned}
& S R=1-\frac{1}{1+\exp (-z)}, \\
& z=\beta_{0}+\beta_{1} T^{2}+\beta_{2} T+\beta_{3} C^{2}+\beta_{4} C+\beta_{5} \log (1+t)
\end{aligned}
$$

ここに, $S R$ : 生存率, $T$ : 水温 $\left({ }^{\circ} \mathrm{C}\right), C$ : 塩分濃度 (psu)， $t$ :経過時間（hour）， $z$ :線形予測子， $\beta_{0} \sim \beta_{5}$ : 係数. 経過時間については，実験開始時（0時間）と2時 間経過から260時間までの4時間ごと，計45時期を対象と 


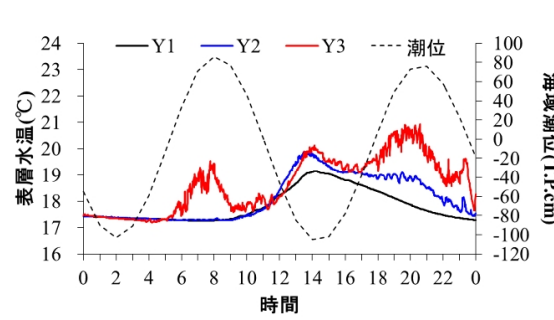

$\mathrm{a}-1)$ 水温(Y1～Y3)

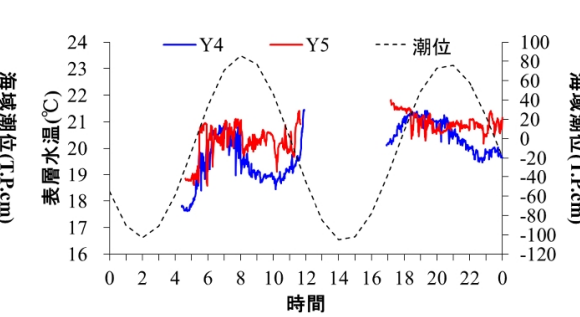

$\mathrm{a}-2)$ 水温(Y4,Y5)

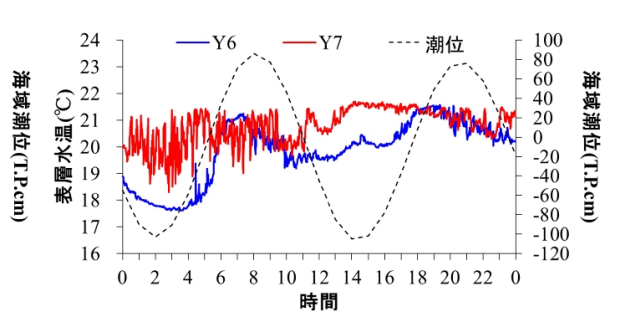

a-3) 水温(Y6,Y7)

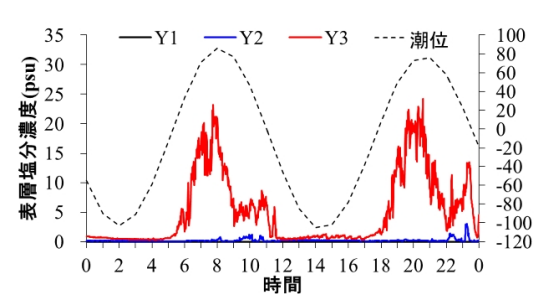

b-1) 塩分濃度(Y1～Y3)

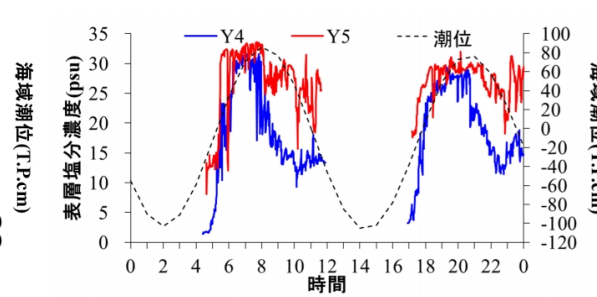

b-2) 塩分濃度 $(Y 4, Y 5)$

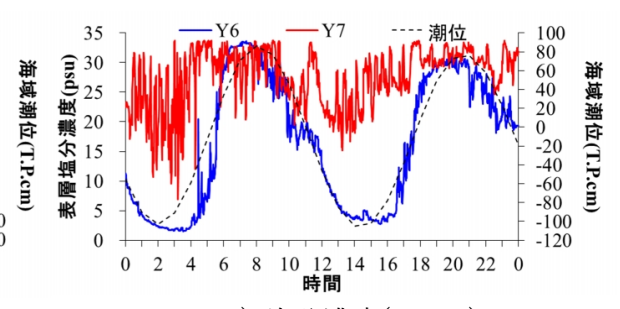

b-3) 塩分濃度 $(Y 6, Y 7)$

図-2 役勝川における観測結果

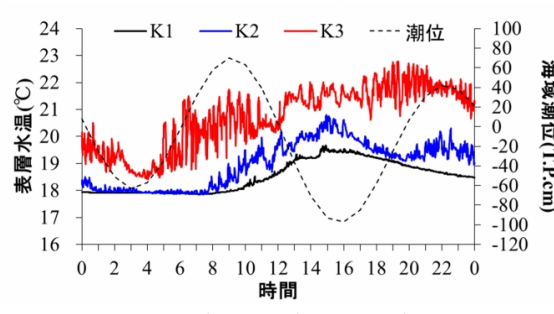

$\mathrm{a}-1)$ 水温 $(\mathrm{K} 1 \sim \mathrm{K} 3)$

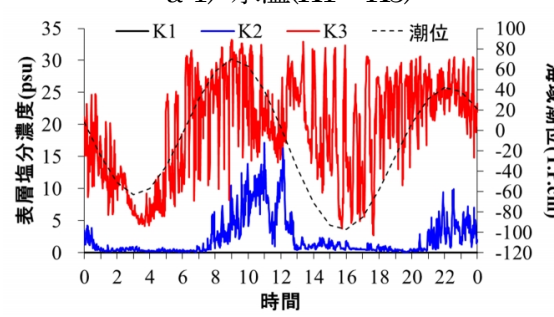

$\mathrm{b}-1)$ 塩分濃度 $(\mathrm{K} 1 \sim \mathrm{K} 3)$

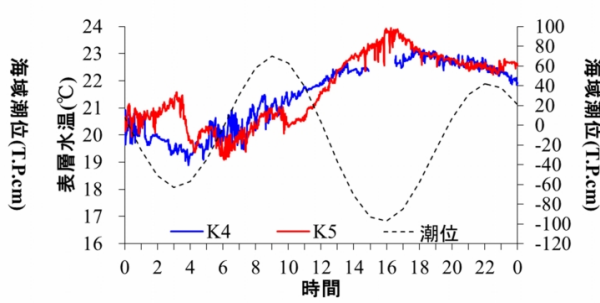

$\mathrm{a}-2)$ 水温 $(\mathrm{K} 4, \mathrm{~K} 5)$

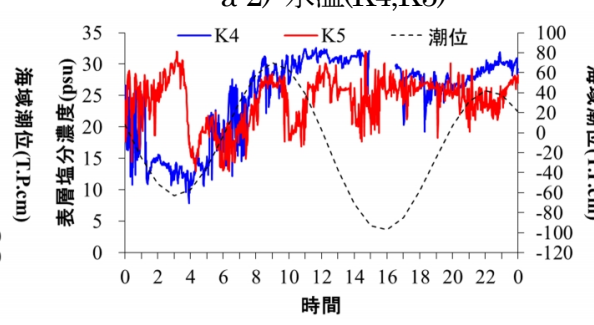

b-2) 塩分濃度(K4,K5)

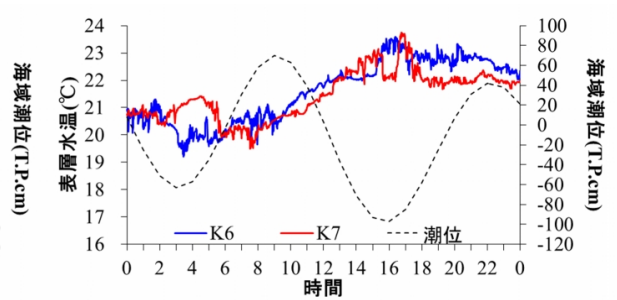

$\mathrm{a}-3)$ 水温(K6.K7)

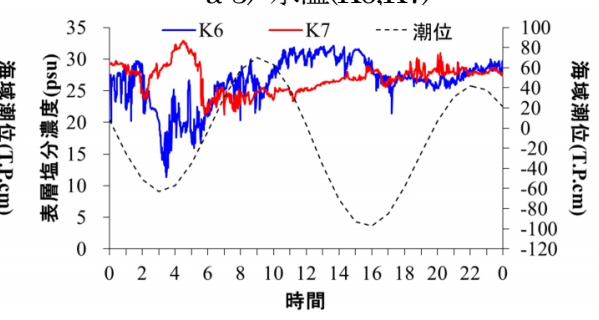

b-3) 塩分濃度(K6,K7)

図-3 河内川における観測結果

し，それまでにすべての個体が死亡した場合も生存数 0 としパラメータに加えた。すべてのパラメータの組み合 わせに対し最尤法を用いて係数值を決定，モデルのAIC (赤池情報量基準) を算出しモデル選択を行った. AIC はモデルの効率性，優秀さを示し，少ないパラメータで 当てはまりの良いモデルほど小さな值となる．統計解析 には統計解析ソフトR version2.10.0を用いた。 リュウ キュウアユ仔稚魚に対する物理環境の好適度を図る指標 として室内生存試験結果から推定される24時間生存率を 選定した. 24時間の生存率を用いたのは，環境而性を測 る上での魚類学上の慣習と潮汐と河川水の変動周期を考 慮したことによる.作成したモデルに1分間隔で得られ る観測值 $(T, C)$ 及び, 経過時間 $t=24$ (hour) を代入し, 24時間分の推定值を平均することで定義した. これに加 え環境変化一の応答を見るために現況の各時刻における 水温值から $+1^{\circ} \mathrm{C} 及 ひ ゙-1{ }^{\circ} \mathrm{C} し た$ 仮想の水温值についても生 存率の推定を行った.

\section{3. 結果}

\section{（1）水温・塩分濃度の観測結果}

図-2に役勝川河口域，図-3に河内川河口域における水 温・塩分濃度の観測結果を示す．まず表層水温変動につ いては両河口とも，河川域から海域に向かうに従い水温 が上昇し, 日中をピークとする河川水温の日変動成分と 海水の侵入による半日周期成分の重市わせで構成され ており，海域からの距離が長くなるほど半日周期成分の 影響量が低減し河川水の日周期成分が卓越してくる。 た，感潮域においては水温・塩分濃度とも数十分程度の 短周期変動成分を有しており, 湾のセイシュの影響を受 けていることがわかる.

河川ごとに見ると，役勝川においては，河川域のY1 では $17.5^{\circ} \mathrm{C}$ か $19.2^{\circ} \mathrm{C}$ で午後14時にピークを迎えた. $\mathrm{Y} 2$ では午前中はY1とほぼ同じ変動であるものの, ピーク 值が約 $1{ }^{\circ} \mathrm{C}$ 高く, それ以降の水温が高く潮汐の影響が伺 えた，Y3，Y6では潮汐による影響を強く受け，上げ潮 時に水温が上昇した。満潮時にはY 3 で $20^{\circ} \mathrm{C}, \mathrm{Y} 6$ では $21.5^{\circ} \mathrm{C}$ まで水温が上昇した. Y7では未明の干潮時に水温 が低下したが日中の干潮時にはほとんど低下しなかった。 

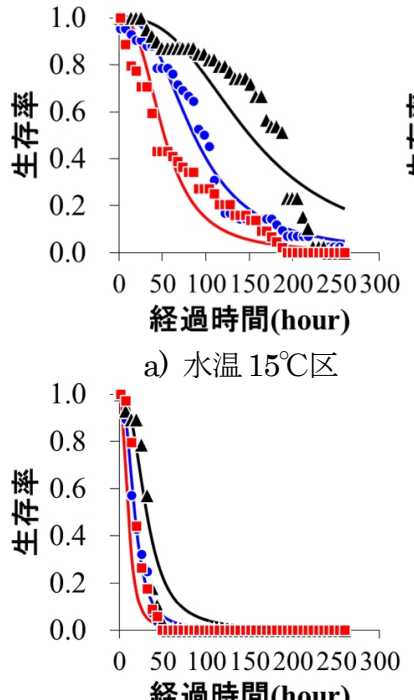

経過時間(hour)

c) 水温 $21^{\circ} \mathrm{C}$ 区

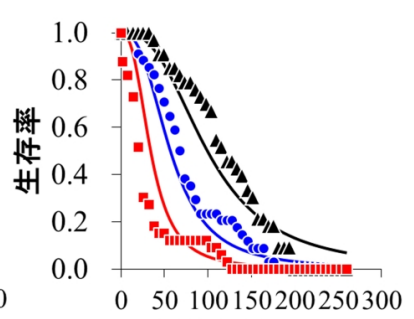

経過時間(hour)

b) 水温 $19^{\circ} \mathrm{C}$ 区

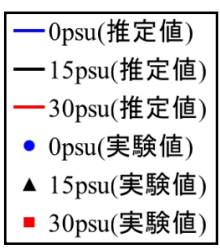

- 30psu(実験値)
図-4 生存実験結果とモデルによる推定值曲線
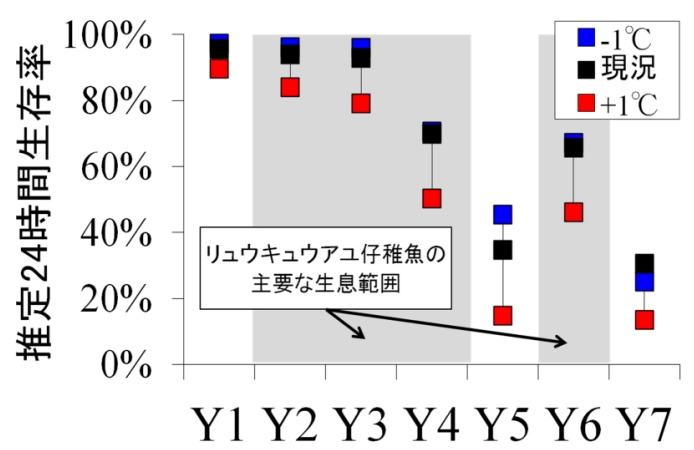

a) 役勝川

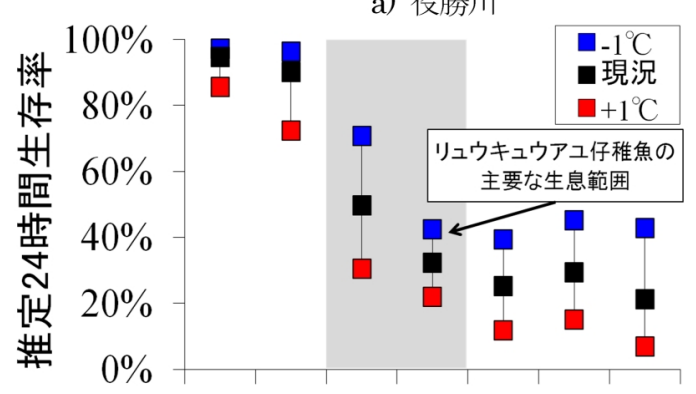

\section{K1 K2 K3 K4 K5 K6 K7}

b) 河内川

図-5 推定生存率算定結果

干潟域に位置するY4，Y5については冠水後，潮位の上 昇に伴い水温がY7の海域と同程度まで上昇した。 下げ 潮になると, Y4では水温・塩分ともに低下し, 干出直 前まで $19^{\circ} \mathrm{C} ， 20 \mathrm{psu}$ 程度でほぼ横ばいとなった．Y5につ いても水温・塩分濃度ともY4より高いが変動傾向は類 似した。河内川については，河川域のK1での水温は役

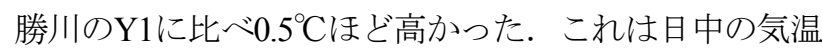
が影響している（観測時の気象庁観測所平均気温:役勝 川観測時 $18.5^{\circ} \mathrm{C}$ ，河内川観測時: $\left.21.6^{\circ} \mathrm{C}\right) 。 \mathrm{~K} 2$ では若干潮 汐の影響を受けるが河川からの影響が強い．実質的な河 口に位置するK3は，未明の干潮時を除き強く高温の海 水の影響を受けており, 潮位とK50観測結果に現れる

\begin{tabular}{|c|c|c|c|c|c|c|c|c|}
\hline & \multirow{2}{*}{ AIC } & \multirow{2}{*}{$\Delta \mathrm{AIC}$} & \multicolumn{6}{|c|}{ 係数の推定値 } \\
\hline & & & $\beta_{0}$ & $\beta_{1}$ & $\beta_{2}$ & $\beta_{3}$ & $\beta_{4}$ & $\beta_{5}$ \\
\hline 1 & 1712 & 0 & 43.4 & 0.21 & -6.85 & 0.01 & -0.24 & 2.71 \\
\hline 2 & 2136 & 424 & -14.6 & 0.01 & - & 0.01 & -0.23 & 2.52 \\
\hline 3 & 2204 & 492 & -18.6 & - & 0.49 & 0.01 & -0.23 & 2.49 \\
\hline Null & 11045 & 9334 & 0.86 & - & - & - & - & - \\
\hline \multirow{4}{*}{\multicolumn{2}{|c|}{$\begin{array}{l}\mathrm{AIC} \text { 上位 (小値) } \\
10 モ テ ゙ ル の \text { 概要 }\end{array}$}} & 採択数 & & 7 & 7 & 6 & 6 & 10 \\
\hline & & 平均 & & 0.04 & -1.02 & 0.00 & -0.04 & 1.09 \\
\hline & & 最大値 & & 0.21 & 0.49 & 0.01 & 0.03 & 2.71 \\
\hline & & 最小値 & & 0.01 & -6.85 & 0.00 & -0.24 & 1.75 \\
\hline
\end{tabular}

海水温の上昇に伴って水温が上昇を続けた. 日中の干潮 時でも水温が下がる傾向は殆ど無く, 一日の大部分で $20^{\circ} \mathrm{C}$ 以上の高水温状態が持続していた. K4，K5，K6, K7は海域の焼内湾に位置するが，4点とも水温は類似し た変動を見せ，未明に $20^{\circ} \mathrm{C}$ 程度，そこから 15 時の干潮時 にかけて水温が $23^{\circ} \mathrm{C}$ 程度まで上昇した，K4は河口澪筋 K3 の至近にある干潟部上に位置するものの，水温につ いては沖合の観測地点と顕著な差は見られなかった。た だし塩分濃度については，K4，K5，K6では干潮時に 20psu程度まで低下寸る傾向が見られた。

\section{（2）モデリング結果と生存率推定結果}

表-1に推定した生存率モデルについて示す. AICが最 も小さく最良と判断されたモデルは，すべての係数を含 むモデルであった. 次点とのAICの差は424.5, 次々点と は491.7であり，採択されたモデルが他を大きく引き離 してAICが小さく，良好なモデルであると言える．実験 值との比較を行った結果が図-4である. 推定式は傾向と しては概ね実験結果を表現できている.

図-5に各観測地点における現況の推定24時間生存率及 び，仮想水温值 $\left(+1^{\circ} \mathrm{C},-1^{\circ} \mathrm{C}\right)$ における推定 24 時間生存 率，及び表層塩分濃度，表層水温の観測結果を示寸．役 勝川河口域においては, 現在の主な生息域であるY2,

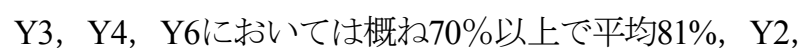
Y3では $90 \%$ を超える推定生存率を示した。河川域である Y1においても推定值が高かった。逆に干潟上に位置す るY5や海域に位置するY7においては $35 \% ， 31 \%$ と低い 推定值が得られた. 仮想的な水温值についての応答を見 ると, $+1^{\circ} \mathrm{C}$ の昇に対しては河川域を除き概ね $20 \%$ 前後 の低下を示した－ $-1{ }^{\circ} \mathrm{C}$ の低下に対しては干潟域に位置す るY5では若干推定值が上昇したが，他の地点において は大きな変化を見せなかった．河内川河口域における推 定值を見ると，現在の主要な生息域であるK $3 ， \mathrm{~K} 4$ にお いて $50 \% ， 32 \%$ と役勝川の推定值に比べ低い值を示した. 役勝川の生息域における值との差は平均で40\%であった. また，沖側のK4～K7に関しては $20 \% 〜 30 \% の$ 極めて低 い推定值が算出された. 一方, 感潮区間の河道域に位置 するK2，河川域に位置するK1においては $90 \%$ 以上の高 い推定值が得られた．仮想水温に対する応答については, 水温の上昇, 下降ともに顕著な応答を見せた. $+1^{\circ} \mathrm{C}$ の上 昇について主要生息域であるK 3 では $20 \%$ の低下， $-1{ }^{\circ} \mathrm{C} の$ 
低下については $20 \%$ \%昇を見せた，海域についても同 様に鋭敏に反応した．河川域については水温低下につい ては特段大きな変化を見せなかったが，水温上昇に対し てはK1で約 $10 \% ， \mathrm{~K} 2 て ゙ は$ 約 $20 \%$ の生存率の低下が算出 された.

\section{4. 考察}

\section{（1）水温 - 塩分濃度変動特性の差異についての検討}

両対象地の生息分布における水温変動特性は大槻 ${ }^{5)}$ の報告と同様，役勝川では $20^{\circ} \mathrm{C}$ 以下，河内川では $20^{\circ} \mathrm{C}$ 以 上の水温が卓越していた. このような水温特性の差異を 検討する上で着目すべき点が役勝川干潟域に位置する Y4の変動である．Y4では満潮から干潮にかけてほぼ一 定值の低水温・低塩分值が得られた。この時間帯に干潟 域に淡海水が混合され一時的に貯留されていたと考えら れる. 仔稚魚生存率は $20^{\circ} \mathrm{C}$ 以下の水温では $15 \mathrm{psu}$ で最も 高くなるが4)，この時観測されたのも $20^{\circ} \mathrm{C}$ 以下・約 $15 \mathrm{psu}$ の水塊であった. 干潟水域の広く浅い地形特性は淡海水 の混合にプラスに働くことは想像されるが，対象両河口 域には流域面積にして2.4倍異なり流入淡水流量に大き な差があるため, 観測值の夕から変動特性の差異が河口 域構造の相違によるものと定量的に評価することは難し い. 3次元流動シミュレーション等によるさらなる検討 が必要である.

\section{（2）生理的好適条件と生息分布の比較}

塩分濃度, 水温観測結果に基づくリュウキュウアユ仔 稚魚に対する推定生存率を算出したところ, 役勝川では 現在の生息域で70 $90 \%$ ，河内川では約30 50\%と河口間 で明瞭な差異が認められた。役勝川におけるリュウキュ ウアユ仔稚魚の主な生息域は，概略的にみてハビタット において $20^{\circ} \mathrm{C}$ 以下の水温を観測する期間が長く, 生理的 な生息条件は比較的好適と考えられ，河内川における リュウキュウアユ仔稚魚の生息域はK $3 ， \mathrm{~K} 4$ 地点に集中 しているが，水温・塩分濃度とも高く, 生理的な生息条 件は役勝川に比べ劣悪と考えられた。

役勝川のリュウキュウアユ仔稚魚生息域における評価 值を仮にリュウキュウアユ仔稚魚が求める適切な好適度 と考えると，河内川の生息域において本種が生理的に適 切に生息寸るためには評価值でおよそ $30 \%$ 分の差異があ ると言える. 空間分布で見ると, 役勝川でも河内川でも 河川域から海域に向かうに従って推定生存率が低下して いたが，河内川における低下率は役勝川における低下率 に比べ急勾配であり，人為改変による影響として急激な 生理的好適条件の変化が生じていると考えられる.

推定24時間生存率と生息分布とを比較すると，役勝川 においては推定生存率と生息分布が概致一致した。一方 河内川においては，現在の生息分布では推定生存率が低
$<$, 生息密度の低い河道部（K2）では高いという空間 的な不一致が見られた.このことから，河内川河道部に おける仔稚魚の個体数の少なさについては生理的要因以 外の制限要因の影響が推察される.このことについて岸 野・四宮 ${ }^{4}$ は䬺資源量密度の相違を指摘している. リュ ウキュウアユに限らず両側回遊型の魚類が仔稚魚期に海 に降るのは慨資源の獲得が主たる目的であることが指摘 されていることから ${ }^{1)}$, 生理的環境条件の良否以上に生 息分布を制限されることは可能性の高い現象であると考 えられる。

\section{（3）感度分析結果から見る過去の水温上昇による影響}

推定生存率の温度に対寸る感度分析から, 役勝川では 水温下降に対してそれほど鋭敏な反応を示さなかったの に対し，河内川においては主なハビタットとなるK3に おいて約 $20 \%$ の推定值の上昇が見られた。この值は役勝 川のハビタットにおける数值と遜色なく, $-1^{\circ} \mathrm{C}$ 程度の水 温効果によって役勝川と同等の生理的好適条件を実現で きるという生息域の環境回復の可能性を示すものと考え られる。一方で, 河内川生息域においては僅かな水温変 化にもリュウキュウアュの生息環境に大きく影響すると 考えられる. 奄美大島が属する東シ十海海域の海水温は 過去 100 年間で $1.44^{\circ} \mathrm{C}$ 程度上昇したとされており ${ }^{9)}$ ，河内 川河口海域においても海水温の上昇が生じた可能性は あったと思われる. 河内川における仔稚魚生息域がこの ような水温に対し敏感な領域に限定されていることは, 過去の長期的な水温上昇の影響が色濃く現れているのか もしれない. かつてリュウキュウアユが生息していた沖 縄島においても河口域の埋め立てや狭险化が起こってい るが，絶滅要因についてこれまで言われているような瀬 淵構造の消失等 ${ }^{10)}$ 成魚期の生息域となる中流域の問題 以外にも河口域の影響も検討すべきであると考えられる。 さらに, $+1^{\circ} \mathrm{C}$ 感度分析結果に見るように, 河内川のみ ならず役勝川においても推定生存率の低下がみられ，今 後の僅かな水温上昇がリュウキュウアユに与える影響は 極めて大きいと思われる. 本種の保護, ひいては奄美大 島の生物多様性の劣化の阻止に向け, 早急な対策を講じ る必要があると思われる。

\section{（4）評価手法の妥当性}

本研究では室内生存実験結果を野外に適用する方法で 生息場評価を行った.これまで生息場評価に関して多く の研究が行われ，その代表的な手法としてPHABSIMが ある.これは物理的要素を計算する部分と, 対象生物種 の物理量に対する選好度（選好曲線）を定義する部分で 構成され，両者の重祇合わせ重み付き利用可能面積を算 出しその大小で評価を行なう手法であるが，選好曲線は ある環境における対象種の在/不在データをベースとし て与えることが一般的である. しかし在/不在データを 生物の好適環境をはかる上で用いることは妥当でない場 
合がある．改変された環境においては制約が多すぎてや むなく悪化した環境に生息しているとき，生息している 環境が良い環境とは言えない場合が想定されるためであ る.このような場面は特に生息域が限定されている希少 種や対象種に関する情報が少ない場合に多いと思われる。

その点, 本手法は評価から生息分布を一旦切り離すこ とで，改変等によって偏った生息分布に依らない対象生 物が持つ本来の好適を評価することを目指した点は妥当 であったと思われる．河内川の河道部におけるK1，K2 地点の評価結果が示すように，仔稚魚の生息分布を必ず しも表現できてはいないが, 総体としてではなく生理的 な好適度という部分を評価している点が明瞭であるので, 実生息場においては生理的好適度の比較ができ, 評価点 が高く生息が確認されない点においては, 生息制限要因 を生理的要因とは異なるというある程度の予測を立てる ことができる. 本研究における手法の検証は難しい面が あるが，多くの生物種においてなされている而性実験を 現場に適用寸ることは生息場評価の技術的・実務的な一 つのアプローチとして提示できると思われる.

\section{5. 結論}

本研究では奄美大島のみに生息する絶滅危惧種, リュ ウキュウアユ仔稚魚の生育場評価を目的に, 現地調査結 果及び生存試験結果に基づく統計的モデルを用いて，役 勝川・河内川の環境の対照的な両河口域において推定生 存率から生理的な環境の好適度の評価・比較を行った. 以下に得られた知見をまとめる.

(1)リュウキュウアユ仔稚魚の生育環境評価のため, 仔 稚魚の生理的好適度を示寸と考えられる生存試験結果を ベースとした生存率推定モデルを作成した。現地観測結 果と重祮合わせ24時間生存率を推定した。

(2) 対照的な河口域を持つ役勝川と河内川における表層 水温及び塩分濃度の連続観測の結果, 役勝川生息域にお ける水温・塩分濃度は河内川の生息域に比べともに低く, 干潟域では満潮後に低水温・低塩分值が観測されるなど 河内川に見られない水温・塩分濃度変化傾向が見られた。 (3) 推定した生理的好適度の比較を行ったところ, 両河 口の生息域における推定24時間生存率は約30\%異なり, 河内川の生息域は生理的な観点から役勝川における生息 域に比べ劣悪であることが示唆された.

(4) 推定生存率の高い地点と実際の生息域を比較すると, 役勝川では両者は概ね重なりあうのに対し，河内川では 生息域で低く個体数の少ない河道部で高いという不一致 が見られた. 河道部の生息密度の低さには生理的要因以 外の生息制限要因の影響も大きいと推察された.

(5) 仮想的な水温值（現況 $\pm 1^{\circ} \mathrm{C}$ ) を用いた推定 24 時間生 存率の感度分析を行った. 仮想の水温低下に対して役勝
川における反応は鈍感だったが，河内川においては温度 変化に対する変化量が大きかった. 河内川では僅かな水 温の上昇もリュウキュウアユに影響を与えうることを示 していると考えられた。

謝辞 : 本研究の遂行にあたり四宮明彦教授（鹿児島大学 水産学部）及び岸野底博士（河川環境調査）にはデー夕 の提供等多大なるご助力を頂いた. また本研究は日本学 術振興会科学研究費補助金基盤研究 (B) (課題番 号:22310050 研究代表者:島谷幸宏) 及び同特別研究員奨 励費（大槻順朗）の一部を使用した。 ここに深甚なる謝 意を表します。

\section{参考文献}

1) 田中 克, 田川正朋, 中山耕至 : 稚魚 生存と変態の 生理生態学, 京都大学学術出版会, 2009

2) 四宮明彦：リュウキュウアユ.「日本の希少淡水魚の 現状と系統保存—よみがえれ日本産淡水魚一」（長 田芳和, 細谷和海編) , 緑書房, pp.36-47, 1997

3) 岸野 底, 四宮明彦: 奄美大島の役勝川におけるリュ ウキュウアユの遡上生態, 日本水産学会誌, 第69巻, pp.624-631，2003

4) 岸野 底, 四宮明彦: 奄美大島住用湾および焼内湾周 辺におけるリュウキュウアユ仔稚魚の回帰遡上，魚類 学雑誌, 第52巻, pp.115-124, 2005

5) 大槻順朗, 島谷幸宏, 四宮明彦, 上野女やな, 河口洋 一: リュウキュウアユ保全に向けた干潟マングローブ 域の水域冷却機能の現地観測, 水工学論文集, 第35巻, pp.1213-1218, 2009

6) 大槻順朗，池松伸也，島谷幸宏，冬季亜熱帯河口域の 持つ吸熱作用による水温低下効果とリュウキュウアユ 保全手法に関する考察, 河川技術論文集, 第16巻, pp.513-518，2010

7) 二瓶泰雄, 網島康雄, 佐藤正也, 青木康哲, 佐藤慶太, 灘岡和夫 : 現地観測に基づくマングローブ域の水温・ 放射環境に関する研究, 海岸工学論文集, 第49巻, pp.1206-1210, 2002

8) 岸野 底, 四宮明彦, 寿 浩義 : リュウキュウアュ仔 魚の水温・塩分而性に関する生存実験, 魚類学雑誌, 第55巻, pp.1-8, 2008

9) 気象庁 福岡管区気象台・長崎海洋気象台・沖縄気象 台：異常気象レポート 九州・山口県・沖縄版2009 九州・山口県・沖縄の異常気象と気候変動 〜その実 態と見通し〜，2009

10) 西田 睦, 澤志泰正, 西島信昇, 東 幹夫, 藤本治 彦: リュウキュウアユの分布と生息状況一1986年の調 查結果一，日本水産学会誌，58，199-206，1992

(2011. 9. 30受付) 